\title{
IDENTIFYING AVIAN COMMUNITY RESPONSE TO SAGEBRUSH VEGETATION RESTORATION IN Grand Teton National Park
}
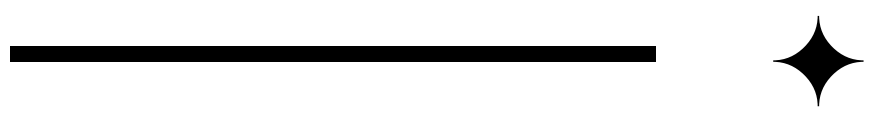

\section{TRACEY N. JOHNSON $\downarrow$ ANNA D. CHALFOUN $\uparrow$ UNIVERSITY OF WYOMING $\uparrow$ LARAMIE}

\begin{abstract}
Approximately $50-60 \%$ of native sagebrush steppe has been lost to non-native grasses, which has contributed to population decreases for sagebrushassociated songbirds. Removal of non-native grasses and restoration treatments may return structure and function of sagebrush steppe and ultimately benefit songbirds, but their responses must be evaluated. To determine breeding songbird community responses to sagebrush restoration treatments, in 2013 we conducted bird surveys at restored plots at the Kelly Hayfields restoration area in Grand Teton National Park, Wyoming. We compared bird communities and vegetation characteristics in restored plots to plots that were unrestored and to areas of native sagebrush steppe as starting and endpoints for restoration, respectively. Unrestored plots were dominated by non-native grasses; restored plots were dominated by forbs and bare ground and had very little shrub cover $(<0.1 \%)$. Native sagebrush plots were dominated by shrubs and native bunchgrasses. Bird community composition was distinct among the three types of plots. Abundance of grassland birds was highest in unrestored plots, and was positively related to cover of non-native grass and litter depth. Abundance of shrubland birds was highest in native sagebrush, and was positively associated with shrub cover. There were very few detections of birds in restored plots, and most species were negatively associated with the high levels of bare ground that characterized these plots. Restored areas may initially ( $\leq 5$ yrs) provide little breeding bird habitat, which should be accounted for when determining schedules of restoration treatments at Kelly Hayfields.
\end{abstract}

\section{$\uparrow \quad$ INTRODUCTION}

Invasive, alien plant and animal species are one of the greatest threats to global biodiversity (Butchart et al. 2010). The effects of invasive aliens on ecosystems are mixed, but they can contribute to disruption of ecosystem functioning, habitat loss and degradation, and extinction of native species (Brooks et al. 2004, Clavero and Garcia-Berthou 2006). Given the potentially negative effects of invasive alien species, control often becomes a priority for conservation and management efforts.

Management of alien plant species may depend on the resilience of the ecosystem into which aliens are introduced. In ecosystems that are resilient, introduction of alien plants often results in temporary changes in relative dominance of plants (Briske et al. 2006). Ecosystems lacking resilience may cross ecological thresholds resulting in permanent dominance of alien species and alternative communities that differ substantially in structure and function from the original community. Returning communities to original structure and function will not likely occur without significant human effort, including alien species control or restoration of native species (Briske et al. 2006). However, restoration of original communities to an original or undisturbed state is often very difficult or unlikely (Van Haveren et al. 1997). A more feasible option may be to restore communities to functional surrogates of their past states, and one way to evaluate the functionality of restored systems is to determine whether the restoration provides suitable conditions for native fauna (Block et al. 2001). 
One system in North America that has been highly converted range-wide is sagebrush steppe. The sagebrush biome, once covering nearly 63 million ha in western North America (Miller and Eddleman 2001), currently comprises almost $300,000 \mathrm{~km} 2$ (Miller et al. 2011). This ecosystem provides substantial services to the nation's economy, including livestock grazing, renewable and non-renewable resources, and recreational opportunities. It also serves as habitat for more than 350 species of wildlife for at least part of their life cycle (Hanser et al. 2011). However, sagebrush systems are among the most threatened in North America (Noss and Peters 1995), largely because of conversion to exotic, annual grasslands (West 2000). Approximately 50-60\% of native sagebrush steppe has been lost to non-native grasses, primarily to provide forage for livestock. Altered plant communities can result in concurrent changes in animal communities as a result of habitat changes. Not surprisingly, the loss of native sagebrush steppe has resulted in decreases of several species of wildlife associated with sagebrush habitat (Knick et al. 2003).

To determine whether restoration efforts in sagebrush steppe can provide functional wildlife habitat similar to original, native habitats, many attributes of wildlife populations using restored areas should be measured, including resource selection and demography (Block et al. 2001). However, an important first step in determining whether restored areas can serve as functional habitat for sagebrushassociated wildlife species is to evaluate occurrence, density, and community composition at restored sites relative to unrestored habitats, and to areas of native, undisturbed vegetation. Including unrestored habitats as restoration starting points and native, undisturbed habitat as restoration endpoints will help determine whether restored habitats are on appropriate trajectories in terms of community composition, and how far restoration goals are from being attained. We focus on breeding songbird responses because grassland and shrubland birds associated with native sagebrush steppe have experienced steep population declines over the last four decades (Sauer et al. 2012), and thus represent taxa that could benefit from successful restoration of sagebrush steppe. The objectives of this study were to evaluate short-term effects of current restoration treatments on 1) the abundance and community composition of birds associated with native sagebrush steppe, and 2) habitat variables important in determining the composition of these bird communities.

Table 1. Restoration plots and associated schedule of restoration efforts at Kelly Hayfields at Grand Teton National Park, Wyoming, USA. Glyphosate treatments are intended to kill smooth brome (Bromus inermis). Milestone treatments are used to treat exotic forbs such as houndstongue (Cynoglossum officinale) and musk thistle (Carduus nutans). Cover crops of winter wheat (Triticum aestivum) and cereal rye (Secale cereale) are used initially instead of native seed mixes to allow for the suppression of annual exotic plants. All bird and vegetation sampling were completed before 2013 treatments.

\begin{tabular}{|c|c|c|c|c|}
\hline \multirow[b]{2}{*}{ Restoration Unit } & \multirow[b]{2}{*}{ Acres } & \multicolumn{3}{|c|}{ Restoration Method } \\
\hline & & Sprayed & Burned & Seeded \\
\hline \multirow[t]{3}{*}{ Aspen Ridge } & 89 & Glyphosate June 2008 & September 2008 & October $2009^{a}$ \\
\hline & & Glyphosate July 2009 & & \\
\hline & & Milestone summer 2010 & & \\
\hline \multirow[t]{2}{*}{ Hunter East/West } & $64 / 122$ & Glyphosate June 2009 & September 2008 & September $2009^{b}$ \\
\hline & & Glyphosate June 2010 & & $\begin{array}{l}\text { September } 2010^{c} \\
\text { October } 2011^{\mathrm{a}}\end{array}$ \\
\hline \multirow[t]{2}{*}{ Elbo West* } & 43 & Glyphosate June 2010 & September 2010 & September $2010^{\mathrm{c}}$ \\
\hline & & Glyphosate July 2010 & & October $2011^{\mathrm{a}}$ \\
\hline \multirow[t]{2}{*}{ Elbo East } & 225 & Glyphosate June 2011 & May 2010 & September $2012^{c}$ \\
\hline & & Glyphosate June 2013 & & \\
\hline Henrie & 324 & Glyphosate June 2013 & & \\
\hline \multicolumn{5}{|c|}{ * not included in vegetation or avian monitoring } \\
\hline \multicolumn{5}{|l|}{ a Native seed mix } \\
\hline
\end{tabular}




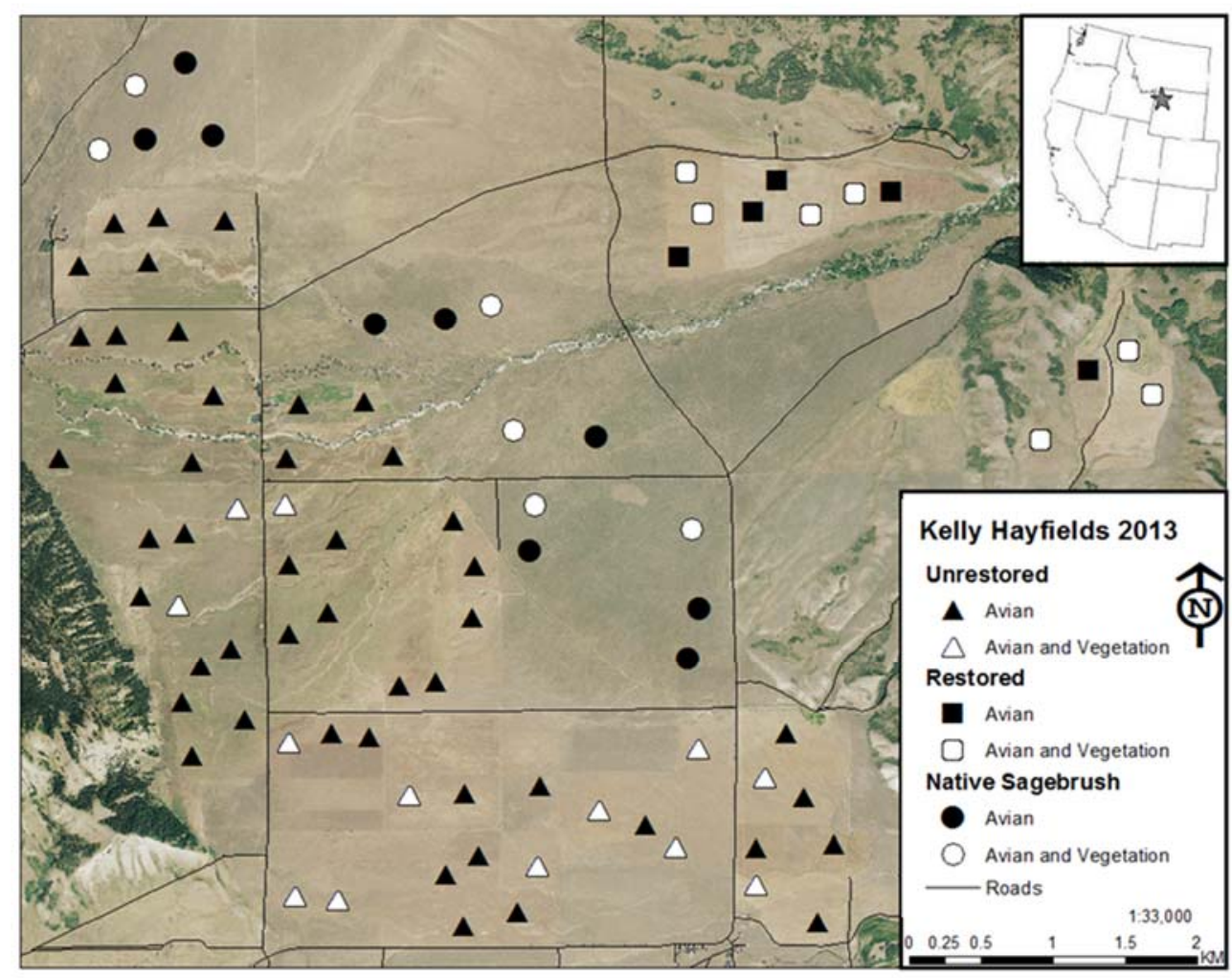

Figure 1. Avian and vegetation survey locations within Kelly Hayfields Grand Teton National Park, Wyoming, USA.

\section{STUDY AREA}

To assess whether restored sites provide functional habitat for sagebrush-associated songbirds, we conducted surveys for breeding birds at unrestored and recently-restored plots already established by National Park Service (NPS) personnel in Grand Teton National Park (GTNP), Wyoming, USA. Additionally, we identified and surveyed areas of native sagebrush steppe that represented a restoration end goal in order to make comparisons to restored and unrestored plots (Figure 1). Although GTNP lands are characterized by a number of different ecological zones, lower elevations are primarily conifer and deciduous forests intermixed with extensive sagebrush steppe in drier upland areas. Prior to establishment of GTNP, land now known as the Kelly Hayfields was settled by homesteaders who converted native sagebrush steppe vegetation to non-native pasture for agricultural use. Since the NPS acquired the land in the 1960s, agricultural use has been minimal. However, non-native vegetation in areas previously used as pastures remains dominant. In 2007, in cooperation with the US Fish and Wildlife Service, the NPS committed to restoring the Kelly Hayfields to native sagebrush steppe with the "Bison and Elk Management Plan". Restoration treatments began at
Kelly Hayfields in 2008 (Table 1). The total restoration goal is 1790 ha. At the time of data collection, restoration treatments had been completed on 36 ha, and an additional 184 ha were being actively treated. We conducted surveys on plots $(n=4)$ that were in various stages of restoration (either very recently completed or being actively treated in the year of our surveys; Table 1). In addition to data collection at restored plots, bird surveys were conducted at plots $(n=9)$ in the Kelly Hayfields that have not undergone any restoration treatments (Figure 1); these units serve as a baseline point of comparison. Finally, to serve as a restoration endpoint of comparison, bird surveys were conducted in plots $(n=3)$ of native sagebrush steppe near the Kelly Hayfields (Figure 1). These plots were established by visual inspection of dominant vegetation, and by avoiding areas intersected by road, areas potentially influenced by changes in topography or soil type, and an area near the Hayfields that had been affected by a recent fire (NPS personnel, personal communication). Including non-native, unrestored plots and native sagebrushdominated plots in the sampling design with restored sites provides us with a continuum of vegetation characteristics that will allow us to assess avian community responses to restoration treatments throughout the restoration process. 


\section{METHODS}

\section{Avian surveys}

To quantify bird abundance and community composition, 5 min fixed radius point count surveys were conducted in all 16 plots using the removal method (Farnsworth et al. 2002). Counts were divided into five, 1-min intervals, and all birds detected within $100 \mathrm{~m}$ were recorded only once and subsequently 'removed' (ignored) from the sample population after initial detection to estimate detection probability. Five-minute counts also help minimize the likelihood that individual birds are mistakenly thought to be multiple birds and counted more than once (Fuller and Langslow 1984). Surveys were conducted from 3-14 June 2013 to minimize the likelihood of including migrants during counts (Rehm-Lorber et al. 2010). We established 2-5 survey points within each plot depending on plot size (Figure 1). Points were located a minimum of $150 \mathrm{~m}$ from features that might influence vegetation or detection of birds (e.g., roads, fences, or riparian zones) and $250 \mathrm{~m}$ from each other. Surveys began within 15 min of dawn and continued until 0930 Mountain Standard Time. Surveys were not conducted during periods of continuous rain, or wind causing tree tops to bend (Beaufort Wind Scale 5). Each survey point was visited twice throughout the sampling period.

\section{Vegetation surveys}

Vegetation surveys were conducted at two of the points in each plot used for bird surveys. We used a $90-\mathrm{m}$ line transect originating at the point and extending in one direction determined by a radial degree chosen at random. Vegetation characteristics were recorded along three distance intervals from the origin (0-10 m, 40-50 m, and 80-90 m). Within each $10 \mathrm{~m}$ distance interval, measurements were made on the shrub canopy (if present) and understory at $1 \mathrm{~m}$ intervals $(n=30$ points along each transect). Percent shrub cover was assessed by recording and summing the linear distances along each transect directly intercepted by shrub canopy, and dividing by 30 . Height of each shrub intersecting the transect line was also measured, and the species recorded. Understory characteristics were assessed using point intercept along the same transect: species intercepted first (top canopy), second (lower canopy), and soil surface characteristics were evaluated at each $1 \mathrm{~m}$ interval. Functional cover types were recorded, which included native and non-native grasses, forbs, and standing dead material, and live plants were identified to genus or species when possible. Soil surface was characterized as a functional type or species if a plant's base was intercepted, or litter, bare ground, rock, or cryptogam. Vegetation height $(\mathrm{cm})$ and litter depth $(\mathrm{mm})$ was measured at each 1-m interval.

\section{Statistical analyses}

We attempted to estimate songbird densities using the Farnsworth removal model (Farnsworth et al. 2002) which allows estimation of detection probabilities and adjusts estimates of abundance based on detection rates. However, sparse numbers of observations for any species at restored plots precluded use of this method. So, for the remainder of our analyses, we used the maximum count of each species from two visits within a plot as our response variable. We recognize there are limitations to inferences we can make from our data because we have not accounted for differences in detection probability among species or habitats. However, during initial modeling of songbird density, we estimated very high detection probabilities $(\rho)$ for species that occurred in sufficient numbers to be modeled for native and unrestored treatments, which included Brewer's Sparrow $(\rho>0.92)$, Savannah Sparrow $(\rho>0.97)$, Green-tailed Towhee $(\rho>0.91)$, Vesper Sparrow $(\rho>0.69)$, and Western Meadowlark $(\rho>0.98)$, suggesting low detection probabilities and large differences among species may not have strongly influenced our results.

To compare songbird community composition among native sagebrush steppe, restored, and unrestored areas, and to describe relationships among songbird community composition and vegetation characteristics, we used a multivariate approach. To determine whether there were differences in community composition among plot types, we conducted a Multi-Response Permutation Procedure using abundance of each species (MRPP; Mielke 1984). Plot types were used as a priori groups for comparison of community composition. Distances were calculated using the Euclidian measure and groups were defined by plot type (native sagebrush steppe: $\mathrm{n}=3$; restored: $\mathrm{n}=4$; unrestored: $\mathrm{n}=9$ ).

Non-metric multidimensional scaling (NMS) was used to elucidate results of the MRPP analysis and to evaluate the relationship between songbird community composition and habitat characteristics (Kruskal 1964, Mather 1976). Euclidian distance measure was used for the NMS. Final dimensionality of the data was evaluated using final stress versus the number of dimensions, where stress is a measure of departure from monotonicity between distance in original species space and distance in ordination space, and by performing 225 runs of a randomization 
test (McCune and Grace 2002). To describe habitat factors influencing patterns of breeding songbird community composition, habitat measurements were overlaid onto the final ordination. These measurements included: percent cover of shrubs, native and non-native grasses, and bare ground, as well as litter depth and understory height. We determined which habitat measurements to include based on a review of the primary literature for specieshabitat associations. Correlation coefficients of vectors from the habitat matrix represent the strength and direction of relationships with axes. We conducted all multivariate analyses in PC-ORD Version 6.08 (McCune and Mefford 2011).

\section{$\downarrow \quad$ RESULTS}

We observed 24 bird species, eight of which have established associations with some component of native sagebrush steppe habitat (Table 2; Rich et al. 2005). The most common species were shrubland and grassland-associated species, including: Brewer's Sparrow (Spizella breweri), Brewer's Blackbird (Euphagus cyanocephalus), Green-tailed Towhee (Pipilo chlorurus), Long-billed Curlew (Numenius americanus), Savannah Sparrow (Passerculus sandwichensis), Vesper Sparrow (Pooecetes gramineus), Western Meadowlark (Sturnella neglecta), and Sage Thrasher (Oreoscoptes montanus). Mean number of species ranged from 1-6 for all plots (Table 3). Similar numbers of species were observed in native and unrestored plots, and the fewest species were detected in restored plots. Savannah Sparrow and Western Meadowlark were most abundant at unrestored plots (Table 4). Brewer's Sparrow, Green-tailed Towhee, and Sage Thrasher were most abundant at native sagebrush steppe plots. Vesper Sparrow abundance was relatively low and similar among treatments.

Vegetation composition and structure was substantially different among the three plot types. Native plots were characterized by relatively high percent cover of shrubs, native bunchgrasses and forbs, and litter cover (Table 5). Restored plots had relatively high percent cover of native and non-native forbs and bare ground, and low cover of shrubs or grasses. Unrestored plots were dominated by nonnative grass (primarily Bromus inermis) and had high percent litter cover relative to restored plots. Depth of the litter layer and height of the understory (grasses + forbs) was lowest in restored plots (Table 6). Shrub height was greatest in native sagebrush plots, and although some unrestored plots had a shrub

Table 2. Total number of detections for all species observed during point count surveys in native sagebrush steppe $(n=$ $3)$, restored $(n=4)$, and unrestored $(n=9)$ plots in the Kelly Hayfield area of Grand Teton National Park, Wyoming, USA in 2013.

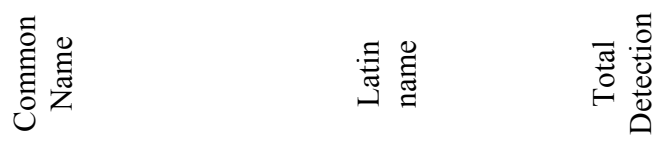

\begin{tabular}{|c|c|c|}
\hline Savannah Sparrow & Passerculus sandwichensis & 134 \\
\hline Brewer's Sparrow & Spizella breweri & 112 \\
\hline Vesper Sparrow & Pooecetes gramineus & 69 \\
\hline Western Meadowlark & Sturnella neglecta & 41 \\
\hline Green-Tailed Towhee & Pipilo chlorurus & 32 \\
\hline Brewer's Blackbird & Euphagus cyanocephalus & 10 \\
\hline Long-billed Curlew & Numenius americanus & 10 \\
\hline Common Raven & Corvus corax & 8 \\
\hline Sage Thrasher & Oreoscoptes montanus & 7 \\
\hline American Robin & Turdus migratorius & 3 \\
\hline Tree Swallow & Tachycineta bicolor & 3 \\
\hline Barn Swallow & Hirundo rustica & 2 \\
\hline Canada Goose & Branta canadensis & 2 \\
\hline Mountain Bluebird & Sialia currucoides & 2 \\
\hline Sprague's Pipit & Anthus spragueii & 2 \\
\hline American Kestrel & Falco sparverius & 1 \\
\hline Black-billed Magpie & Pica hudsonia & 1 \\
\hline European Starling & Sturnus vulgaris & 1 \\
\hline Lincoln's Sparrow & Melospiza lincolnii & 1 \\
\hline Merlin & Falco columbarius & 1 \\
\hline Northern Flicker & Colaptes auratus & 1 \\
\hline Turkey Vulture & Cathartes aura & 1 \\
\hline Violet-green Swallow & Tachycineta thalassina & 1 \\
\hline White-crowned & & \\
\hline Sparrow & Zonotrichia leucophrys & 1 \\
\hline
\end{tabular}


Table 3. Mean number of species $( \pm$ SE) observed within native sagebrush steppe $(n=3)$, restored $(n=4)$, and unrestored $(n=9)$ plots at the Kelly Hayfield area of Grand Teton National Park, Wyoming, USA during 2013.

Treatment Mean no. species

\begin{tabular}{lc}
\hline Native & $4.67( \pm 0.67)$ \\
Restored & $2.33( \pm 0.67)$ \\
Unrestored & $4.42( \pm 0.53)$ \\
\hline
\end{tabular}

component (Table 5), average shrub height was much lower $($ difference $=48.41 \mathrm{~cm}$ ) compared to native plots (Table 6).

The MRPP test using songbird abundances in native sagebrush, restored, and unrestored plot types as a priori groups yielded a large $\mathrm{A}$-statistic $(\mathrm{A}=0.36$, p-value $<0.0001)$, reflecting distinct songbird community composition in each plot type and high within-group homogeneity. Pairwise comparisons revealed that all three plot types had unique species composition (Table 7). Based on examination of $\mathrm{T}$ values, native versus unrestored plots had the strongest differences in species composition, while native versus restored and restored versus unrestored had similar magnitudes of difference between them.
Table 4. Mean number of observations ( $\pm \mathrm{SE}$ ) of sage brush steppe-associated songbird species in native sagebrush steppe $(n=3)$, restored $(n=4)$, and unrestored $(n=9)$ plots at the Kelly Hayfield area of Grand Teton National Park, Wyoming, USA. Values reported are means of the maximum number of observations of each species from two visits to each plot during 2013.

Treatment

\begin{tabular}{lrrr} 
Species & Native & Restored & Unrestored \\
\hline & & & \\
Savannah & 0 & 1.00 & 7.33 \\
Sparrow & $( \pm 0.00)$ & $( \pm 1.00)$ & $( \pm 1.00)$ \\
& & & \\
Brewer's & 16.0 & 0.25 & 1.67 \\
Sparrow & $( \pm 2.65)$ & $( \pm 0.25)$ & $( \pm 0.86)$ \\
& & & \\
Vesper & 2.33 & 3.25 & 2.50 \\
Sparrow & $( \pm 1.20)$ & $( \pm 1.49)$ & $( \pm 0.58)$ \\
& & & \\
Western & 1.00 & 0.50 & 2.42 \\
Meadowlark & $( \pm 0.58)$ & $( \pm 0.50)$ & $( \pm 0.62)$ \\
& & & 0 \\
Green-Tailed & 6.67 & 0 & $( \pm 0.00)$ \\
Towhee & $( \pm 2.85)$ & $( \pm 0.00)$ & 0 \\
& & & $( \pm 0.00)$ \\
\hline Sage Thrasher & $( \pm 1.15)$ & $( \pm 0.00)$ &
\end{tabular}

Table 5. Mean percent cover ( \pm SE) by functional type in native sagebrush steppe $(n=3)$, restored $(n=4)$, and unrestored $(n=9)$ plots at the Kelly Hayfields area of Grand Teton National Park, Wyoming, USA.

\begin{tabular}{|c|c|c|c|c|c|c|c|}
\hline Treatment & $\begin{array}{c}\text { \% Shrub } \\
\text { cover }\end{array}$ & $\begin{array}{c}\% \text { Native } \\
\text { grass }\end{array}$ & $\begin{array}{c}\% \text { Non- } \\
\text { native } \\
\text { grass }\end{array}$ & $\begin{array}{l}\% \text { Native } \\
\text { forb }\end{array}$ & $\begin{array}{l}\% \text { Non- } \\
\text { native forb }\end{array}$ & $\begin{array}{l}\% \text { Bare } \\
\text { ground }\end{array}$ & $\%$ Litter \\
\hline Native & $\begin{array}{r}11.23 \\
( \pm 2.25)\end{array}$ & $\begin{array}{r}5.78 \\
( \pm 2.71)\end{array}$ & $\begin{array}{r}0.10 \\
( \pm 0.10)\end{array}$ & $\begin{array}{r}15.16 \\
( \pm 1.83)\end{array}$ & $\begin{array}{r}0.56 \\
( \pm 0.56)\end{array}$ & $6.79( \pm 2.03)$ & $\begin{array}{r}81.23 \\
( \pm 7.33)\end{array}$ \\
\hline Restored & $\begin{array}{r}0.05 \\
( \pm 0.05)\end{array}$ & $\begin{array}{r}2.64 \\
( \pm 3.73)\end{array}$ & $5.0( \pm 3.92)$ & $\begin{array}{r}11.81 \\
( \pm 5.25)\end{array}$ & $\begin{array}{r}12.36 \\
( \pm 6.76)\end{array}$ & $\begin{array}{r}43.61 \\
( \pm 14.32)\end{array}$ & $\begin{array}{r}50.14 \\
( \pm 15.81)\end{array}$ \\
\hline Unrestored & $\begin{array}{r}0.89 \\
( \pm 0.47)\end{array}$ & $\begin{array}{r}1.98 \\
( \pm 1.13) \\
\end{array}$ & $\begin{array}{r}30.65 \\
( \pm 3.59) \\
\end{array}$ & $\begin{array}{r}1.91 \\
( \pm 0.74)\end{array}$ & $\begin{array}{r}4.44 \\
( \pm 2.07) \\
\end{array}$ & $\begin{array}{r}15.56 \\
( \pm 3.36) \\
\end{array}$ & $\begin{array}{r}80.62 \\
( \pm 2.92) \\
\end{array}$ \\
\hline
\end{tabular}


Table 6. Average ( $\pm \mathrm{SE})$ vegetation height and litter depth in native sagebrush steppe $(n=3)$, restored $(n=4)$, and unrestored $(n=9)$ plots at Kelly Hayfields area of Grand Teton National Park, Wyoming, USA in 2013.

\begin{tabular}{lrrr} 
Treatment & $\begin{array}{l}\text { Litter } \\
\text { depth } \\
(\mathrm{mm})\end{array}$ & $\begin{array}{r}\text { Understory } \\
\text { height }(\mathrm{cm})\end{array}$ & $\begin{array}{l}\text { Shrub } \\
\text { height } \\
(\mathrm{cm})\end{array}$ \\
\hline Native & $\begin{array}{r}14.34 \\
( \pm 3.47)\end{array}$ & $\begin{array}{r}13.11 \\
( \pm 2.69)\end{array}$ & $\begin{array}{r}62.42 \\
( \pm 2.65)\end{array}$ \\
& & & \\
Restored & 3.22 & 6.15 & 0.4 \\
& $( \pm 1.66)$ & $( \pm 0.98)$ & $( \pm 0.4)$ \\
& & & \\
Unrestored & $( \pm 3.38)$ & $( \pm 1.23)$ & $( \pm 7.29)$ \\
\hline
\end{tabular}

Table 7. Results of a multi-response permutation procedure comparing breeding songbird community composition sampled in native sagebrush steppe $(n=3)$, restored $(n=4)$ and unrestored $(n=9)$ plots during 2013 at the Kelly Hayfield area of Grand Teton National Park, Wyoming, USA.

\begin{tabular}{lccc}
\hline Comparison & $T^{\mathrm{a}}$ & $A^{\mathrm{b}}$ & $\begin{array}{c}P- \\
\text { value }\end{array}$ \\
\hline Native vs. restored & -3.67 & 0.46 & $<0.01$ \\
Native vs. unrestored & -5.77 & 0.33 & $<0.01$ \\
& & & \\
Restored vs. unrestored & -3.72 & 0.15 & $<0.01$ \\
\hline
\end{tabular}

$\bar{a} T=\left(\delta-m_{\delta}\right) / s_{\delta}$, where $\delta=$ the weighted mean within-group distance, $m_{\delta}=$ mean of $\delta$ under the null hypothesis, and $s_{\delta}=$ standard deviation of $\delta$ under the null hypothesis. The more negative the value of $T$, the larger the difference between groups (McCune and Grace 2002).

${ }^{\mathrm{b}}$ Chance-corrected within-group agreement, describing within-group similarity. The highest possible value for $A$ is 1 (McCune and Grace 2002).

Ordination of the untransformed data yielded a 2-dimensional solution (final stress $=3.52$, instability $<0.0001$ ) and total $\mathrm{R} 2=0.98$ (axis $1: \mathrm{R} 2=$ 0.89 , axis 2 : $\mathrm{R} 2=0.09$ ). The $\mathrm{R} 2$ value represents the variance in the original distance matrix represented in ordination space. Cover of shrubs and native grasses and cover of non-native grass are at opposite ends of axis 1 , suggesting that axis 1 represents a gradient of plant species composition where higher shrub and native grass cover is correlated with less cover of nonnative grass (Figure 2, Table 8). Axis 2 separates cover of non-native grass and litter depth from extent of bare ground and represents a gradient of vegetation structure where higher values of non-native grass cover are positively correlated with litter depth and negatively correlated with extent of bare ground. Sage
Thrasher, Green-tailed Towhee, and Brewer's Sparrow had strong, positive associations with higher cover of shrubs and native bunchgrasses (Table 8, Figure 2). Savannah Sparrow, Western Meadowlark, and Vesper Sparrow had positive associations with a deeper litter layer and higher cover of non-native grass, and negative associations with higher cover of bare ground (Table 8, Figure 2).

Table 8. Correlations of each variable with axes obtained from a non-metric multidimensional scaling ordination of breeding songbird abundance in native sagebrush steppe ( $n$ $=3)$, restored $(n=4)$, and unrestored $(n=9)$ plots at the Kelly Hayfield area of Grand Teton National Park, Wyoming, USA.

\begin{tabular}{|c|c|c|}
\hline \multirow[b]{2}{*}{ Variable } & \multicolumn{2}{|c|}{ Correlation coefficient } \\
\hline & Axis 1 & Axis 2 \\
\hline \multicolumn{3}{|l|}{ Species } \\
\hline Sage Thrasher & 0.77 & 0.31 \\
\hline Green-tailed Towhee & 0.68 & -0.24 \\
\hline Brewer's Sparrow & 0.97 & 0.23 \\
\hline Vesper Sparrow & 0.22 & -0.16 \\
\hline Savannah Sparrow & -0.64 & 0.70 \\
\hline Western Meadowlark & 0.03 & 0.32 \\
\hline \multicolumn{3}{|l|}{ Habitat } \\
\hline$\%$ shrub cover & 0.94 & 0.10 \\
\hline$\%$ native grass & 0.51 & -0.19 \\
\hline$\%$ non-native grass & -0.67 & 0.52 \\
\hline$\%$ bare ground & -0.20 & -0.51 \\
\hline litter depth & 0.27 & 0.63 \\
\hline understory height & 0.24 & 0.33 \\
\hline
\end{tabular}




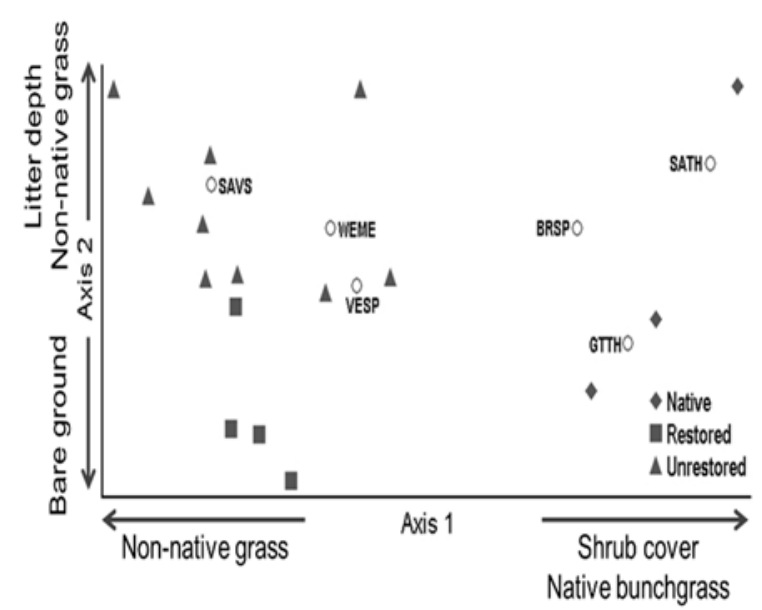

Figure 2. Ordination of native sagebrush steppe, restored, and unrestored plots (2013) in species space using nonmetric multidimensional scaling. Arrows beside axes represent relationships of habitat variables with each axis. Cover of shrubs, native and non-native grasses, and bare ground are presented as percentages, litter depth in $\mathrm{mm}$, and understory height in $\mathrm{cm}$. Species codes: SATH $=$ Sage Thrasher; GTTH $=$ Green-tailed Towhee; BRSP $=$ Brewer's Sparrow; VESP $=$ Vesper Sparrow; SAVS = Savannah Sparrow; WEME $=$ Western Meadowlark.

\section{DISCUSSION AND MANAGEMENT IMPLICATIONS}

This study evaluated the short-term response of songbirds to sagebrush restoration treatments, and our results will contribute to a better understanding of the effects of restoration treatments on sagebrush steppe birds and their habitats. Currently, there is little information available in the primary literature on bird responses to restoration in sagebrush steppe ecosystems. In fact, a recent review of published articles by Ortega-Alvarez and Lindig-Cisneros (2012) of the effects of ecological restoration on birds yielded no studies focused on sagebrush steppe habitats. Although there are studies reporting restoration treatments of sagebrush steppe with the aim of creating or improving Greater Sage-grouse (Centrocercus urophasianus) habitat, the actual effects of restoration of sagebrush habitat on sage grouse populations seemingly have also not been evaluated (e.g., Wisdom et al. 2002, Baker et al. 2009). We found songbird communities of distinct composition among native sagebrush steppe, restored, and unrestored plots. Unsurprisingly, native sagebrush plots with high shrub cover were occupied by sagebrush-associated species including Sage Thrasher, Green-tailed Towhee, and Brewer's
Sparrow (Figure 2). Recently- and actively-restored plots were characterized by a large forb component, sparse shrubs or grasses, and low numbers of bird detections. Thus, restored plots were not associated with the abundance of any bird species (Figure 2). Unrestored plots were dominated by non-native grasses and primarily occupied by grasslandassociated species like Vesper Sparrow, Savannah Sparrow, and Western Meadowlark.

Sparse detections of birds during and shortly after restoration treatments $(\leq 5$ yrs $)$ suggest that restored plots provide little breeding habitat for birds of any species. Restored plots in this study no longer provided breeding habitat for many grassland birds, as grass cover was low and bare ground too extensive (Table 5). Moreover, restored plots also still had very little shrub cover $(<0.1 \%)$, thereby precluding shrubnesting birds. To provide adequate breeding habitat for sagebrush-associated birds (including Greater Sage-grouse), shrub canopy should be approximately $15-30 \%$, or higher (Connelly et al. 2000, Chalfoun and Martin 2007, Holmes and Altman 2012). The shrub species included in restoration treatments in this study (e.g., Artemisia tridentata vaseyana, Chrysothamnus spp.) may immediately begin to establish following seeding, but it may take $A$. tridentata as many as 10 years to dominate a site (Tirmenstein 1999). Grass cover will likely increase before shrub cover, and in the near-term, restored plots may again provide habitat for grassland birds once the extent of bare ground is reduced and an acceptable grass canopy and litter layer develops (Fisher and Davis 2010). However, consideration of our reported patterns of breeding bird abundance and community composition is important for managers when considering schedules for restoration treatments, as many hectares of potential breeding habitat may be removed from the local landscape for $\leq 10$ yrs or more following initial sagebrush restoration treatments.

Although unrestored plots were occupied by grassland birds, we did not evaluate whether they provided high-quality breeding habitat. Unrestored plots were dominated by non-native grasses, which may differ from native habitat in phenology, cover, and invertebrate abundance or species composition (Lloyd and Martin 2005, Kennedy et al. 2009, Johnson and Sandercock 2010, Litt and Steidl 2010), all of which may influence the reproductive success of breeding birds. Thus, without habitat-specific demographic rates, we cannot conclude that removal of breeding habitat via restoration of plots dominated by non-native grasses is detrimental to breeding birds. 


\section{ACKNOWLEDGEMENTS}

Support for this work was provided by the University of Wyoming-National Park Service Research Center and the U.S. Geological Survey Wyoming Cooperative Fish and Wildlife Research Unit. We are grateful for assistance received from Grand Teton National Park personnel, including Kathy Melander, John Stephenson, and Ken Stella. T. Zafforano assisted with preparation of this report.

\section{$\uparrow \quad$ LITERATURE CITED}

Baker, W. L., J. Garner, and P. Lyon. 2009. Effect of imazapic on cheatgrass and native plants in Wyoming big sagebrush restoration for Gunnison sage-grouse. Natural Areas Journal 29(3): 204-209.

Block, W. M., A. B. Franklin, J. P. Ward, J. L. Ganey, and G. C. White. 2001. Design and implementation of monitoring studies to evaluate the success of ecological restoration on wildlife. Restoration Ecology 9(3): 293303.

Briske, D. D., S. D. Fuhlendorf, and F. E. Smeins. 2006. A unified framework for assessment and application of ecological thresholds. Rangeland Ecology and Management 59(3): 225-236.

Brooks, M. L., C. M. D’Antonio, D. M. Richardson, J. B. Grace, J. E. Keeley, J. M. DiTomaso, R. J. Hobbs, M. Pellant, and D. Pyke. 2004. Effects of invasive alien plants on fire regimes. BioScience 54(7): 677-688.

Butchart, S. H., M. Walpole, B. Collen, A. van Strien, J. P. Scharlemann, R. E. Almond, et al. 2010. Global biodiversity: Indicators of recent declines. Science 328(5982): 1164-1168.

Chalfoun, A. D., and T. E. Martin. 2007. Assessments of habitat preferences and quality depend on spatial scale and metrics of fitness. Journal of Applied Ecology 44(5): 983-992.

Clavero, M., and E. Garcia-Berthou. 2005. Invasive species are a leading cause of animal extinctions. Trends in Ecology and Evolution 20(3): 110.

Connelly, J. W., M. A. Schroeder, A. R. Sands and C. E. Braun. 2000. Guidelines to manage sage grouse populations and their habitats. Wildlife Society Bulletin 28: 967-985.

Farnsworth, G. L., K. H. Pollock, J. D. Nichols, T. R. Simons, J. E. Hines, and J. R. Sauer. 2002. A removal model for estimating detection probabilities from point-count surveys. The Auk 119(2): 414-425.
Fisher, R. J., and S. K. Davis. 2010. From Wiens to Robel: A review of grassland-bird habitat selection. The Journal of Wildlife Management 74(2): 265-273.

Fuller, R. J., and D. R. Langslow. 1984. Estimating numbers of birds by point counts: How long should counts last? Bird Study 31(3): 195202.

Hanser, S. E., M. Leu, S. T. Knick, and C. L. Aldridge (eds.). 2011. Sagebrush Ecosystem Conservation and Management: Ecoregional Assessment Tools and Models for the Wyoming Basins. Allen Press, Lawrence, KS.

Holmes, A. L., and B. Altman. 2012. Bird habitat guide: Sagebrush communities in the Intermountain West. PRBO Conservation Science, American Bird Conservancy, and Western Working Group of Partners in Flight. $11 \mathrm{pp}$.

Johnson, T. N., and B. K. Sandercock. 2010. Restoring tallgrass prairie and grassland bird populations in tall fescue pastures with winter grazing. Rangeland Ecology and Management 63(6): 679-688.

Kennedy, P. L., S. J. DeBono, A. M. Bartuszevige, and A. S. Lueders. 2009. Effects of native and non-native grassland plant communities on breeding passerine birds: Implications for restoration of northwest bunchgrass prairie. Restoration Ecology 17(4): 515-525.

Knick, S. T., D. S. Dobkin, J. T. Rotenberry, M. A. Schroeder, W. M. Vander Haegen, and C. van Riper III. 2003. Teetering on the edge or too late? Conservation and research issues for avifauna of sagebrush habitats. The Condor 105(4): 611-634.

Kruskal, J. B. 1964. Nonmetric multidimensional scaling: A numerical method. Psychometrika 29(2): 115-129.

Litt, A. R., and R. J. Steidl. 2010. Insect assemblages change along a gradient of invasion by a nonnative grass. Biological Invasions 12: 3449-3463.

Lloyd, J. D., and T. E. Martin. 2005. Reproductive success of Chestnut-collared Longspurs in native and exotic grassland. The Condor 107(2): 363-374.

Mather, P. M. 1976. Computational Methods of Multivariate Analysis in Physical Geography. John Wiley and Sons, London

McCune, B., and J. B. Grace. 2002. Analysis of Ecological Communities. MjM Software Design, Gleneden Beach, OR. 
McCune, B., and M. J. Mefford. 2011. PC-ORD Multivariate Analysis of Ecological Data. Version 6.08. MjM Software Design, Gleneden Beach, OR.

Mielke, P. W. 1984. Meteorological applications of permutation techniques based on distance functions. Pages 813-830 In: P. R. Krishnaiah, and P. K. Sen (eds.) Handbook of Statistics, Vol.4. Elsevier Science Publishers, The Hague, The Netherlands.

Miller, R. F., and L. Eddleman. 2000. Spatial and temporal changes of Sage Grouse habitat in the sagebrush biome. Agricultural Experiment Station Bulletin 151. Oregon State University, Corvallis, OR.

Miller, R. F., S. T. Knick, D. A. Pyke, C. W. Meinke, S. E. Hanser, M. J. Wisdom, and A. L. Hild. 2011. Characteristics of sagebrush habitats and limitations to long-term conservation. Pages 146-184 In: S. T. Knick and J. W. Connelly (eds.). Greater Sage-grouse: Ecology and Conservation of a Landscape Species and its Habitats. Studies in Avian Biology No. 38. University of California, Berkley, CA.

Noss, R. F., and R. L. Peters. 1995. Endangered Ecosystems: A Status Report on America's Vanishing Habitat and Wildlife. Defenders of Wildlife, Washington, DC.

Ortega-Álvarez, R., and R. Lindig-Cisneros. 2012. Feathering the scene: The effects of ecological restoration on birds and the role birds play in evaluating restoration outcome. Ecological Restoration 30: 116127.
Rehm-Lorber, J. A., J. A. Blakesley, D. C. Pavlacky, and D. J. Hanni. 2010. Monitoring the birds of Wyoming: 2009 field season report. Tech. Rep. M-MWB-09-01. Rocky Mountain Bird Observatory, Brighton, CO.

Rich, T. D., M. J. Wisdom, and V. A. Saab. 2005. Conservation of priority birds in sagebrush ecosystems. U.S. Forest Service Gen. Tech. Rep. PSW-GTR-191. 17 pp.

Sauer, J. R., J. E. Hines, J. E. Fallon, K. L. Pardieck, D. J. Ziolkowski, and W. A. Link. 2012. The North American Breeding Bird Survey, Results and Analysis 1966-2011. Version 07.03.2013.

Tirmenstein, D. 1999. Artemisia tridentata spp. tridentate. In: Fire Effects Information System [Online]. U.S. Department of Agriculture, U.S. Forest Service Rocky Mountain Research Station, Fire Sciences Laboratory. http://www.fs.fed.us/database/feis/ consulted April 1, 2014.

Van Haveren, B. P., J. E. Williams, M. L. Pattison, and J. R. Haugh. 1997. Restoring the ecological integrity of public lands. Journal of Soil and Water Conservation 52(4): 226-231.

West, N. E. 2000. Synecology and disturbance regimes of sagebrush steppe ecosystems. Pages 15-26 In: P. G. Entwistle, A. M. DeBolt, J. H. Kaltenecker, and K. Steenhof (Compilers). Proceedings of the sagebrush steppe ecosystems symposium. U.S. Department of Interior, Bureau of Land Management Publication BLM/ID/PT001001+1150, Boise, ID.

Wisdom, M. J., M. M. Rowland, B. C. Wales, M. A. Hemstrom, W. J. Hann, M. G. Raphael, and T. D. Rich. 2002. Modeled effects of sagebrush-steppe restoration on Greater Sage-Grouse in the Interior Columbia Basin, USA. Conservation Biology 16(5): 12231231. 